\title{
Applying a Living Lab methodology to support innovation in education at a university in South Africa
}

\author{
R CALLAGHAN AND M HERSELMAN
}

\begin{abstract}
The Living Lab paradigm creates open and inter-disciplinary environments where participants can interrogate challenges and co-create solutions. A successful Living Lab context incorporates a clear focus/vision, strong leadership, self-sustainability, a strong sense of community-owned challenges and the potential for sustainable community development. This paper discusses and outlines the elements of Living Labs, and how these have played a role in the establishment of a new Education Living Lab at a University in South Africa. Core values, stakeholders and key success factors of Living Labs are discussed. This is followed by the description of a case study of the establishment process of a Living Lab. The newly established Living Lab already shows success with collaborations and innovation between communities, industry, academia, learners and schools. This is illustrated in an application of the discussions on the Mobile Learning focus area - the first active sub-focus area within the Education Living Lab.
\end{abstract}

Key Words: Co-creation, community empowerment, interdisciplinary research, Living Labs, open innovation, social innovation

\section{Introduction}

The UNDP (United Nations Development Programme, 2011) still describes South Africa as a developing country, mainly because $42.3 \%$ of its estimated 50.59 million people live in what the UNDP describes as multi-dimensional poverty. $17.4 \%$ of the population live below the poverty line, 9.7 million people are functionally illiterate and 12.5 million people are unemployed (Statistics South Africa, 2012). To address this situation, South Africa must grow both its so-called first and third world economies. The South African Government regards Information and Communication Technology (ICT) as an important vehicle to achieve this, which is evident in the ICT Research, Development and Innovation Strategy pursued by the Department of Science and Technology (DST). This strategy envisions a future where "South Africa is an inclusive information society where ICT-based innovation flourishes" (DST, 2007). The role of Education in achieving this vision is of paramount

1. Dr Ronel Callaghan, Faculty of Education, University of Pretoria, Private Bag X20, Hatfield, 0028. Email: ronel.callaghan@up.ac.za

2 Prof. Marlien Herselman: Faculty of Education, University of Pretoria, Private Bag X20, Hatfield, 0028, \& CSIR, Meraka, P.O. Box 395, Pretoria, South Africa. Email: mherselman@csir.co.za

TD The Journal for Transdisciplinary Research in Southern Africa, 11(1) July 2015, pp. 21-38. 
importance. Challenges in the South African Education system are, however, quite complicated and evident in the Basic Education as well as in the Higher Education (HE) sectors (Badat \& Jayed, 2014). The authors mention challenges such as financial and infrastructural issues, the 'bifurcation' of schooling and $\mathrm{HE}$, participation in HE, success rates, unequal standards of learning and performance, and teacher/facilitator quality.

This paper describes how the Living Lab (LL) paradigm is applied to act as a catalyst to address complex challenges in Education whilst working towards the Department of Science and Technology's (DST's) vision for ICT innovation. The Living Lab is used to create an innovation platform where academia, industry, students and other stakeholders can co-create new ideas and concepts that can support their teaching and learning, as well as improve their skills in a quest to address challenges (Guzmán, Del Carpio, Colomo-Palacios \& De Diego, 2013; De Arias, Masi, Dorigo, Fojas, Vega \& Rolon, 2014).

The LL concept is firstly discussed with regard to the core values; the stakeholders; and the African Living Lab experience, as supported by Living Labs in South Africa (LLiSA). Secondly, the inception of an Education Living Lab within the LLiSA network is presented as a case study of these aspects. Discussions are led by the question:

How can the development of an Education LL at a research intensive university comply with the conditions for successful establishment of LLs in South Africa?

\section{Living Labs: General principles and a South African experience}

The Living Lab paradigm creates inter-disciplinary spaces where participants or stakeholders can co-create solutions to challenges. LL research typically incorporates ICT research and development, with a core focus on human-computer interactions (De Arias et al., 2014). LLs are seen as places where input from users as co-creators can be utilised to research the context of ICT use, find new uses, and evaluate new solutions within their everyday contexts (Følstad, 2008).

The importance of LLs as catalysts of innovation is voiced not only in South Africa, but also in African countries. This has been indicated in the Second Action Plan $(2011$ - 2013) of the 8th Africa - EU Strategic Partnership (Science, Information Society, and Space). LLs create opportunities for collaboration between different sectors (public and private), as well as research communities in Africa and Europe. The synergies between the European Union (EU) 2020 Digital Agenda and the African Union (AU) ICT Development Framework create the opportunity to complement investments in, and deployment of, ICT infrastructure.

The nature of the Living Lab environment fosters cooperation, innovation, entrepreneurship and development (Schaffers \& Turkama, 2012). LLs can support Science and Technology, infrastructure and ICT innovation and diffusion (De Arias et al., 2014; Guzmán, Schaffers, Del Carpio \& De la Cruz, 2010) as "key enablers for poverty reduction, economic growth, social development and regional integration" (Cunningham, Cunningham \& Herselman, 2012:6). Various groups (AU Commission, IST-Africa national partners, World Bank, EU Commission, LLiSA, and European Network of Living Labs - ENoLL) support the establishment of more LLs to address Africa's socio-economic and developmental needs (Cunningham, Cunningham \& Herselman, 2012; LLiSA, 2014; ENoLL, 2014). 


\title{
2.1 Core values
}

The Living Labs approach emerged during the 1990s to encourage ICT development and innovation. LL creates an environment (ecosystem/platform) where participants can investigate and co-create innovation. The inter-disciplinary nature of an LL allows different stakeholders to co-operate towards a common broad goal. This implies that a LL can thus be both an environment as well as an approach (ENoLL, 2014; Følstad, 2008; Geerts, 2011).

The idea of 'open innovation' is one of the core principles in an LL (Fahy, Ponce De Leon, Ståhlbröst, Schaffers \& Hongisto, 2007; Guzman, De la Cruz, Schaffers \& Kulkki, 2007; Mulder, Fahy, Hribernik, Velthausz, Feurstein, Garcia, Schaffers, Mirijamdotter \& Ståhlbröst, 2007). The term 'open innovation' was coined by Chesbrough (2003), who advocates open, externally-oriented innovation. An 'open' approach leverages internal and external sources of ideas and utilises the principles of collaboration to manage research and innovation. Living Labs are complex innovation organisations requiring not just physical facilities, but also careful development of key relationships and networks. There is currently no model for developing or managing Living Labs, according to Guzman et al. (2013).

A variety of ICT-specific (mobile, computing, systems engineering), as well as ICT-related topics (e-commerce, e-health, transport, tourism, energy, agriculture and governance) are incorporated in a number of LL environments or platforms (Lievens, Van den Broeck \& Pierson, 2006; MacEachren, Cai, McNeese, Sharmav \& Fuhrmann, 2006). The importance of LLs in emerging economies has also been indicated in a paper by Smit, Herselman, Eloff, Ngassam, Venter, Ntawanga, Chuang and Van Greunen (2011). In the "Southern African context, the focus seems to be on the application of ICT-related products and services as catalysts for capacity building and community development or empowerment" (Herselman, 2011:3). Most of the experience so far in South Africa is in healthcare, wireless communication, and in energy saving, mainly in user-driven innovations (LLiSA, 2014, Coetzee, Du Toit \& Herselman, 2012).

From an African perspective, the LL can be defined as:

\begin{abstract}
Environments, a methodology or an approach which caters for user-driven open innovation within real-life rural and urban settings/communities, where users can collaborate with multiple committed stakeholders (whether NGOs, SMMEs, industrial, academic/research, government institutions or funders) in one or more locations, to become co-creators or co-designers of innovative ideas, processes or products within multidisciplinary environments. Successful deployments can result in improved processes or service delivery, new business models, products or services, and can be replicated (with necessary socio-cultural adaption) to improve overall quality of life and wider socioeconomic impact (including entrepreneurship) in participating and other communities (Cunningham, Herselman E' Cunningham, 2012:27).
\end{abstract}

Core aspects in LLs are thus open innovation, co-creation, being user-driven, and being multi-disciplinary. In order to grow Living Labs and Living Lab networks in Africa, it is important to ensure wide adoption of this definition and to ensure the involvement of communities and all stakeholders to strengthen the co-creation of innovation. The core values of an LL can thus be summarised as a milieu and/or an approach that:

- Is driven by: Users;

- Involves: Real-life communities and multiple stakeholders; 
- Is focused on: Collaboration and co-creation;

- Is aimed at: Multi-disciplinary open innovation;

- Results in: Improved or new products/processes that are replicable and sustainable; and

- Impacts: The socio-economic environment (capacity building, development, empowerment).

Many of these core values are based in, or linked to, their users and other stakeholders. The next section expands on stakeholder considerations in the LL environment.

\subsection{Stakeholders}

Living labs as 'functional places' involve a variety of stakeholders, such as public and private entities, research institutes and universities, and individuals (De Arias et al., 2014). Living Labs are usually anchored in local communities; however, links between LL's, other communities of practice, universities, and large firms create opportunities to learn from the practice and diversity of global technical knowledge (Schaffers \& Turkama, 2012). The Living Labs approach can also help policy makers to understand what works in practice and what kind of policy environment is needed to sustain the various technology solutions. Many governments want to upscale only one solution that fits a specific need, and do not necessarily see the different opportunities for up-scaling to facilitate different needs and processes (Santoro \& Conte, 2009; Merz, Friedland, de Louw, Dörflinger, Maritz, van Rensburg \& Naudé, 2010).

LLiSA supports the notion of participation of at least two participants with "complementary expertise and experience; a common vested interest in the outcomes of enabling users (community) to actively participate in the research, development and innovation process; and at least one stakeholder ensuring the necessary methodological rigor is applied so that results are valid“ (Cunningham, Herselman \& Cunningham, 2012:26).

Stakeholder considerations for an LL can be summarised as:

- Types: Communities, researchers, public entities, private companies, individuals, communities of practice, other LLs;

- Networking: Sharing knowledge, buy-ins, co-creators;

- Knowledge: Diverse, complementary, including methodological rigour;

- Support: Top-down and bottom-up; and

- Purpose: Common vested interest.

These discussions on the nature, core values and stakeholders in an LL indicate that the establishment of an LL can be a challenging exercise. The following discussion therefore focuses on lessons learnt from the LLiSA Network and resulting key success factors for the establishment of an LL.

\subsection{Key success factors: LLiSA network 2009-2014}

Meraka Institute at the Council for Science and Industrial Research (CSIR) hosts the LLiSA network. LLiSA is similar to ENoLL (European network of Living Labs). . The LLiSA network promotes the establishment of Living Labs in Southern Africa and supports and 
facilitates national and international collaboration between developers, research organisations, other LL Networks, industry, and government. The collaboration is focused on the sharing of good practice, tools and methodologies (LLiSA, 2014). Participants meet during annual and other workshops to share experiences, challenges, and best practice. LLiSA members have identified these workshops as a key factor in the development and progress of their LLs. A few key success factors for the establishment of LLs in South Africa were identified during these workshops (Cunningham, Herselman \& Cunningham, 2012):

\subsubsection{Co-creation of a commonly owned vision.}

Primary goals and objectives are established through engagement with all key stakeholders. This process is strengthened by the creation of an institutional memory through the establishment of a sense of community-owned challenges, and identification of good practices through the development of evaluation tools, training modules and databases of stakeholders, and clarifying Intellectual Property Right (IP) issues.

\subsubsection{Strong, focused leadership}

Such leadership should consist of people that understand what the LL aims to achieve. The leadership should own the support and trust of its members and be representative of its network members. Even though not all expertise and contacts need to be in the network itself, the leadership should have complementary skills.

\subsubsection{Self-sustainable from inception}

The multi-disciplinary nature of an LL can create a self-sustainable platform where groups can address a centralised problem from different perspectives, but with the same goal. This can be applied in testing products and services, and for doing research. Industry also finds this as a valuable platform where trust has already been established, as they can test or pilot their proof of concepts with valuable feedback to improve their products and services.

\subsubsection{A strong sense of challenges and the ability to be nimble and responsive to stakeholder needs}

It is important that members within the LL should be able to identify and respond to challenges, successes and opportunities timeously. Regular engagement with stakeholders is thus important, as well as relevant skills development of both members and their communities. This should be done in cooperation with educational and government institutions and other agencies with complementary goals. It can also be achieved through research, training, and the development of guidelines and policies.

\subsubsection{Regular face-to-face interactions}

Face-to-face interactions establish a better understanding and management of member expectations; support the development of trust relationships; overcome cultural differences; provide opportunities for training; and create collaboration opportunities.

\subsubsection{Hosting or co-locating the LL network within an existing strong organisation}

A 'strong organisation' has access to procurement, payment, auditing and reporting systems. It can also provide complementary resources and skills. These are typically government agencies, research organisations, or incubators. It is, however, essential that the board/management of such a partner organisation is committed to the relationship.

\subsubsection{Support for sustainability}

Primary types of these are funding; capacity building; education/training; knowledge sharing; monitoring and evaluation; content creation; and content licencing. 
The next section describes an application of these discussions in the establishment of an Education LL in a research-intensive University in South Africa, within the LLiSA network.

\section{Establishment of an Education Living Lab}

This section describes the results of a two-year establishment process of a Living Lab in Education. The description is in the format of a case study, describing the context, process and key elements, and is illustrated through examples. The data presented here are qualitative in nature and were gathered through workshops, interviews, documents, reflections, and discussions (Babbie \& Mouton, 2001; Yin, 2013).

\subsection{Context}

Practitioners, researchers and industry are investing effort and resources into a myriad of interventions in Southern Africa in attempts to address the unique challenges of the education system. This gave rise to the need for a research unit at the Faculty of Education in a University in South Africa that can act as a hub to foster collaborative, innovative and sustainable research in teaching and learning. The research unit was established within the Living Labs paradigm and the LLiSA network. This provides a formal inter-disciplinary collaborative research space; and access to, and formalising of, partnerships where lecturers, students, teachers, and other external participants can research and seek solutions in the challenging Southern African educational environment.

\subsection{Establishment process}

The establishment of this LL followed a process that resembles an appreciative inquiry (AI) process. The AI process "advocates collective inquiry into the best of what is, in order to imagine what could be, followed by collective design of a desired future state" (Bushe, 2013). The concept of AI supports the establishment process of an LL well in that it corresponds closely to the key concepts of open innovation, co-creation, being user-driven, and multidisciplinary.

The AI process supports phases of Discovery, Dream, Design and Delivery. The Education LL establishment process phases were slightly different, as they started at the Dream phase. Discovery turned out to be an essential part of all the phases. The phases are briefly described here, with examples of actions and participants:

\subsubsection{Dream}

The first few months of development focused on the definition of the purpose and structure of the LL. This involved extensive stakeholder identification, discussions, presentations and workshops. During these sessions, the participants were encouraged to dream about the possibilities of inter-disciplinary and collaborative research in terms of Education challenges. The participants included academics from various faculties at the university (commencing with the Dean of the Faculty of Education), academics and other advisors from other institutions (national and international), institutional support services (Library, Education support, Law, Finances, Research Department, Continuous Professional Development, Institutional Advancement), schools (private and Government), the Department of Basic Education, and some Industry partners. 
The outcomes of this phase were a description of the Education LL, a preliminary structure, and initial aims. A broad focus was identified as to focus on innovative and sustainable contributions in teaching interventions in order to address the educational challenges in the Southern African context. Sub-focus areas also developed during these discussions and included Mobile Learning, Inquiry-based Learning and Visualisation in Teaching and Learning. An extensive list of stakeholders and advisors was created in the process.

\subsubsection{Design}

During this phase, documentation was created to formalise the design of the envisaged LL. This included the refined purpose, vision, mission and structure. The Mobile Learning subLL focus area naturally developed during this phase in parallel with other developments. This phase also included the initialisation process of approval through the University structures in collaboration with the Research and Innovation Department.

\subsubsection{Develop}

During this phase, collaboration and networking were initialised through workshops, discussions and virtual communications. Buy-ins from stakeholders, and their contributions to the planning and structure of the LL were obtained. The formalisation process to establish the LL as a research unit within the University continued throughout the design and development phases. This implied final documentation preparation and the presentation of the proposal to the relevant fora. This included host departmental approval, presentation and approval at the Faculty Research Committee, the Faculty Teaching and Learning Committee and the Faculty Board. The last step was the approval of the Institution's Research Committee and relevant top management members.

\subsubsection{Apply}

The Mobile Learning focus area commenced with the application of the LL paradigm as an experimental application of the LL structure that was developed. This is discussed in detail in the next section.

\subsubsection{Implement}

The formal implementation of the Education LL commenced after completion of institutional processes and the launch of the lab. A conference was planned to support stakeholder collaboration and idea generation to expand the mobile learning focus, and the other sub-focus areas that were identified and developed.

\subsubsection{Review}

This is a continuous process, and is supported by reflections from stakeholders, evaluations of programmes and interactions, and adaptations to the structure and activities, as identified. This process also forms part of the institutional requirements for research units and is structured accordingly.

Table 1 summarises the current structure of the Living Lab in Innovative Teaching research. It depicts the LL with its users as inter-disciplinary education researchers, focusing on a broad common goal. A core team manages the LL. This team adapts to each sub-LL focus. The community is the broader Education community of lecturers, teachers and trainers. The application of this living Lab is illustrated in a discussion of the Mobile Learning focus that follows. 
Table 1: Living Lab structure

\begin{tabular}{|c|c|}
\hline Living Lab & Living Lab for Innovative Teaching Research \\
\hline Focus question & $\begin{array}{l}\text { How can collaborative, open, user-centric and multi-disciplinary research } \\
\text { promote innovative and sustainable solutions for the challenges in the } \\
\text { Southern African educational environment? }\end{array}$ \\
\hline Vision & $\begin{array}{l}\text { Innovation catalyst: A hub for research on innovative solutions for the } \\
\text { challenges in the Southern African teaching environment, recognised for } \\
\text { its quality, relevance and impact; } \\
\text { Collaborative environment: An open, user-centric, multi-disciplinary } \\
\text { research environment, driven by user-communities and their real life } \\
\text { experiments, fostering innovation and sustainability in teaching } \\
\text { interventions in South Africa; and } \\
\text { Capacity building: Developing people, creating knowledge and making a } \\
\text { difference in education locally and globally. }\end{array}$ \\
\hline $\begin{array}{l}\text { Research } \\
\text { Approach }\end{array}$ & Over-arching: Living Lab research approach \\
\hline Users & Inter-disciplinary education researchers. \\
\hline Community & $\begin{array}{l}\text { Inter-disciplinary education community: } \\
\text { Lecturers, teachers, trainers, post-graduate students, researchers. }\end{array}$ \\
\hline Management & $\begin{array}{l}\text { Core management team: Unit manager, information manager, focus-area } \\
\text { representatives, and advisors. }\end{array}$ \\
\hline $\begin{array}{l}\text { Business } \\
\text { model }\end{array}$ & $\begin{array}{l}\text { Self-sustainable through collaborative projects with education, research, } \\
\text { public and industry partners }\end{array}$ \\
\hline Stakeholders & $\begin{array}{l}\text { Research partners: Academics, post-graduate students, other researchers } \\
\text { (national and international); } \\
\text { Resource partners: Host institution, Industry, Project partners; } \\
\text { Support partners: Host institutional research, law, financial, education, } \\
\text { and technology support; } \\
\text { Advisors and councils: Advisory board of experts; Research councils; and } \\
\text { Teaching and training partners: Departments of Education, Academic } \\
\text { institutions, Industry training sectors. }\end{array}$ \\
\hline $\begin{array}{l}\text { University } \\
\text { structures }\end{array}$ & $\begin{array}{l}\text { The unit is established within an academic department, in the Faculty of } \\
\text { Education, and in the research stream of the Department of Research } \\
\text { and Innovation in a research-intensive university in South Africa. }\end{array}$ \\
\hline $\begin{array}{l}\text { Broader } \\
\text { network }\end{array}$ & ( \\
\hline
\end{tabular}

The functioning of this Living Lab was dependent on the application of innovation processes (Figure 1 below), which link with the AI processes described above. 'Idea identification' links with the 'dream' process, and the 'develop' process links with concept validation. The concept of a 'demo plan' links with the 'develop' process, and customer validation links with both the 'apply' and 'implement' stages. The growth plan links with 'review' as an AI process. This is illustrated in Figure 1 below (Innovation-Management, 2015): 


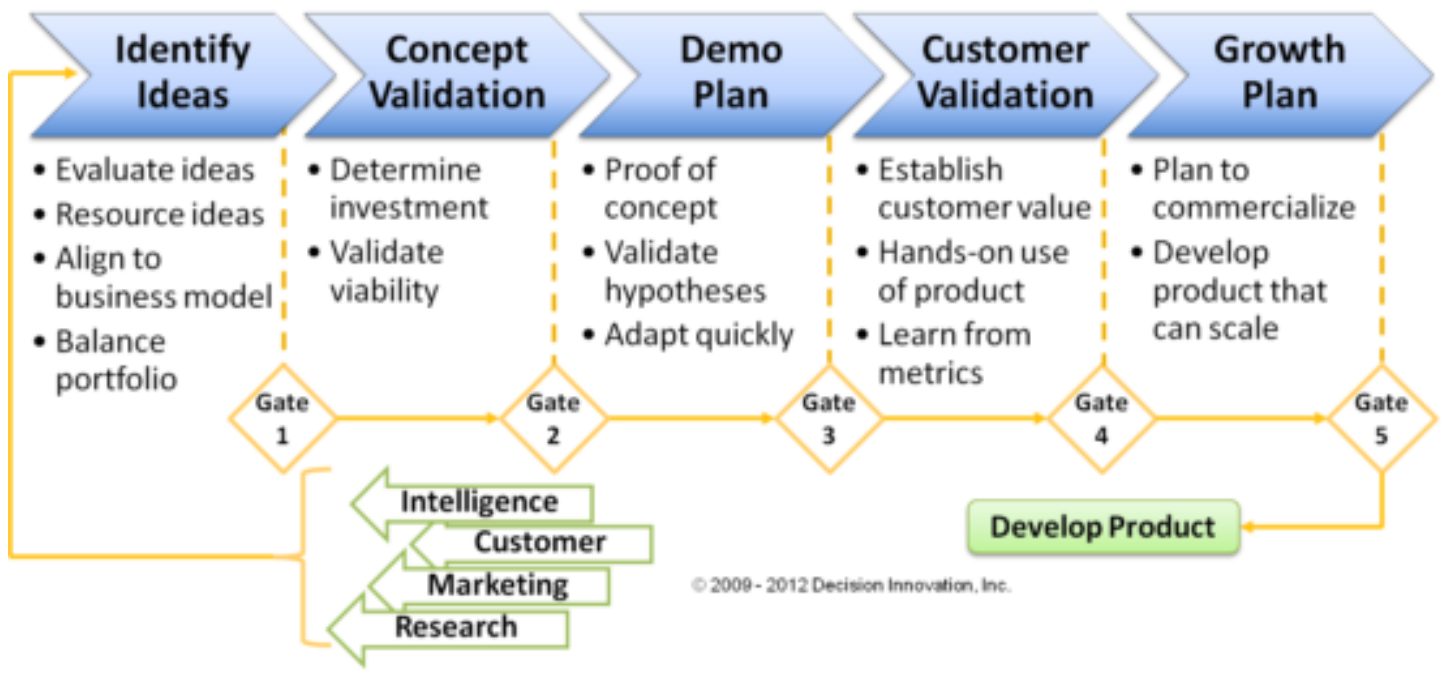

Figure 1: Innovation processes Source: Innovation-Management (2015)

These innovation processes also link with the processes that are applied in Living Labs, as illustrated below (Katzy, 2012).

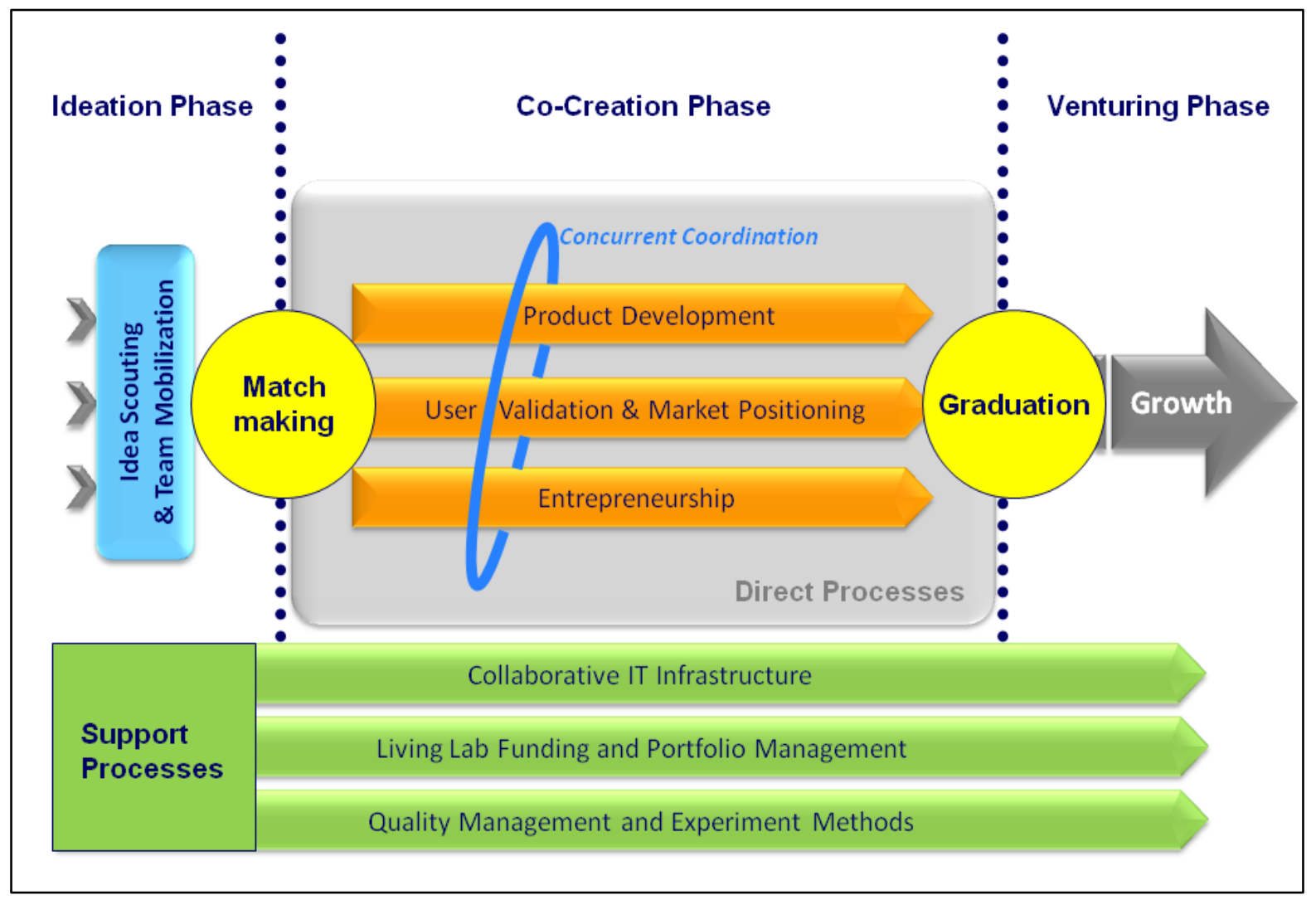

Figure 2: Innovation processes of a Living Lab (Katzy, 2012)

These AI and Living Lab innovation processes were all applied in the mobile learning subfocus, which is discussed below. 


\subsection{The mobile learning sub-focus}

The Education LL envisions the active participation of different sub-focus areas within the broader focus of the Lab: The promotion of innovative and sustainable solutions for the challenges in the Southern African educational environment. This section describes the Mobile Learning (ML) sub-focus area ('Mobile technologies in Education') as an illustration of the LL implementation in this research unit in terms of how the context, core values, stakeholders and key success factors were applied during the different Living Lab innovation processes, as illustrated in figure 2 above.

\subsubsection{The Ideation Phase}

During this phase, it was important to generate ideas on how the recent and continuous developments in the Mobile Learning focus area create possibilities as well as challenges for stakeholders (Bidin \& Zidin, 2013). This became evident in discussions with teachers, lecturers, as well as trainers, thus indicating the need to investigate, experiment with, be trained in and exposed to ML innovations and implementation. In ML, as in all other information fields, an abundance of electronic material is being created and made available to educators. Educators face the challenge, not only to utilise mobile devices to their full capacity, but also to select and/or develop relevant and quality material and applications that will support interactive and high level learning experiences.

\subsubsection{Co-creation phase}

The idea phase led to the co-creation phase. Research was undertaken to investigate the use, acceptance, challenges of and options in ML in Education. Research projects identified during this phase were: Development of an ML course for $21^{\text {st }}$ century facilitators; sourcing and evaluation of ML resources; ML acceptance, and ML applications (App) development. These projects were developed with inputs from various stakeholders and users, and each project provided focus, purpose and funding for the activities. Each project involved different (but also overlapping) LL community members and stakeholders. The research within these areas also overlapped. Each project was managed through face-to-face workshops, as well as virtual communications. The University structures supported the research well. Other support factors (as seen in figure 2 above) were also built into each project (funding; capacity building; education/training; knowledge sharing; monitoring and evaluation; content creation; and content licencing).

\subsubsection{The core values of an LL}

The core values were identified as being driven by users, involving real life communities and multiple stakeholders, focusing on collaboration and co-creation, being aimed at multidisciplinary open innovation, resulting in improved products, and influencing the socioeconomic environment. This was applied in the ML sub-focus as follows, and involved user validation during the co-creation phase, as illustrated in figure 2 above:

The users were the researchers and post-graduate students working in the ML sub-focus area. The communities involved included teachers, schools, other researchers, private and public entities, and industry, as discussed in the next section.

Collaboration and co-creation with users: Each of the interventions / projects focused on collaboration and co-creation. The E-resource research can be seen as an example of cocreation as it involved ten lecturers from four departments in the faculty who worked in five Basic Education subject areas in all school phases towards guidelines for the selection and application of relevant e-resources in ML. Conflict between the different levels of the 
stakeholders and users provided insight into the needs of the ML focus and ultimately supported validation. Postgraduate students' needs are different from lecturers and industry partners, and all these had to be considered.

Multi-disciplinary: The broad aim of the ML sub-focus is to provide a multi-disciplinary workspace where participants can find and share innovative solutions to challenges. This was already applied in the different projects as each project brought stakeholders together from different disciplines in working towards a specific goal. It was also planned for future overarching interventions that would aim to bring the different groups together to share experiences, not only in ML, but also in the broader focus of the LL.

Innovation and impact: One of the results of the ML sub-focus is the ML course that supported facilitators in the design of interactive ML interventions. These courses are presented to inter-disciplinary groups of participants, resulting in innovation in their own practice as teachers and trainers, and therefore also resulting in empowerment and influencing their environments. This was achieved when the developed ML course was implemented during 2014-2015. Stakeholders from academia, industry and practitioners in NGOs or SMEs attended the ML course and had to provide evidence of their interpretation of the different modules in their own environments or context. This forced them to apply the knowledge that was gained and to apply it (as an innovation process) in their own real-life contexts. Through this process, they became co-creators of new knowledge, as this has never been done in their context before. This knowledge was shared and they added new knowledge to already existing knowledge on ML.

\subsubsection{Stakeholder considerations}

Various stakeholders validated or evaluated their evidence. Stakeholder considerations were summarised as consisting of different types, as communicating through networking, with diverse and complementary knowledge, were well supported, and had a common goal. This is illustrated in the ML sub focus as follows:

Stakeholders in the ML sub-focus include lecturers in different subject areas in the Education, as well as in other Faculties at the University, post-graduate students focusing their research on ML, the CSIR, Industry partners providing mobile devices and ML software, the schools implementing or planning to implement ML, and the Provincial Departments of Education. The inter-disciplinary nature of these stakeholders drives innovation in the respective projects.

Networking in this focus area is well established within each project (intra-project), and participants are co-creators of innovations. However, there is also a need for inter-project networking opportunities. A database of stakeholders and other researchers in the field is currently being developed, but this also needs more input at this stage. A virtual network is also being established, but is still in the initial phase.

Diverse and complementary knowledge: Due to the nature of the projects, stakeholders are quite diverse (ranging from Honours to Doctorate students, lecturers in all school phases and subjects, teachers from private and public schools, headmasters, Government officials, and dedicated industry partners). The fact that the unit is established as a research unit implies that a core requirement for the core users of the LL, and thus of each project, is the inclusion of researchers - ensuring methodological rigour.

Stakeholder support: The LL was created for the community, by the community. Each member brings his own network and expertise to support each other; support is therefore also 
a network in nature. The institution also provides support on various levels for researchers. A Champion manages each project and that person supports the participants where necessary.

Common vested interest: All stakeholders within each of the ML projects focus on their specific areas. These participants are also interested and excited (and sometimes worried by) the broader possibilities, challenges and opportunities of ML in Education, thus sharing a common vested interest.

In the following figure, it is indicated what role the users and stakeholders have played as cocreators during the different innovation phases of this LL in Education development:

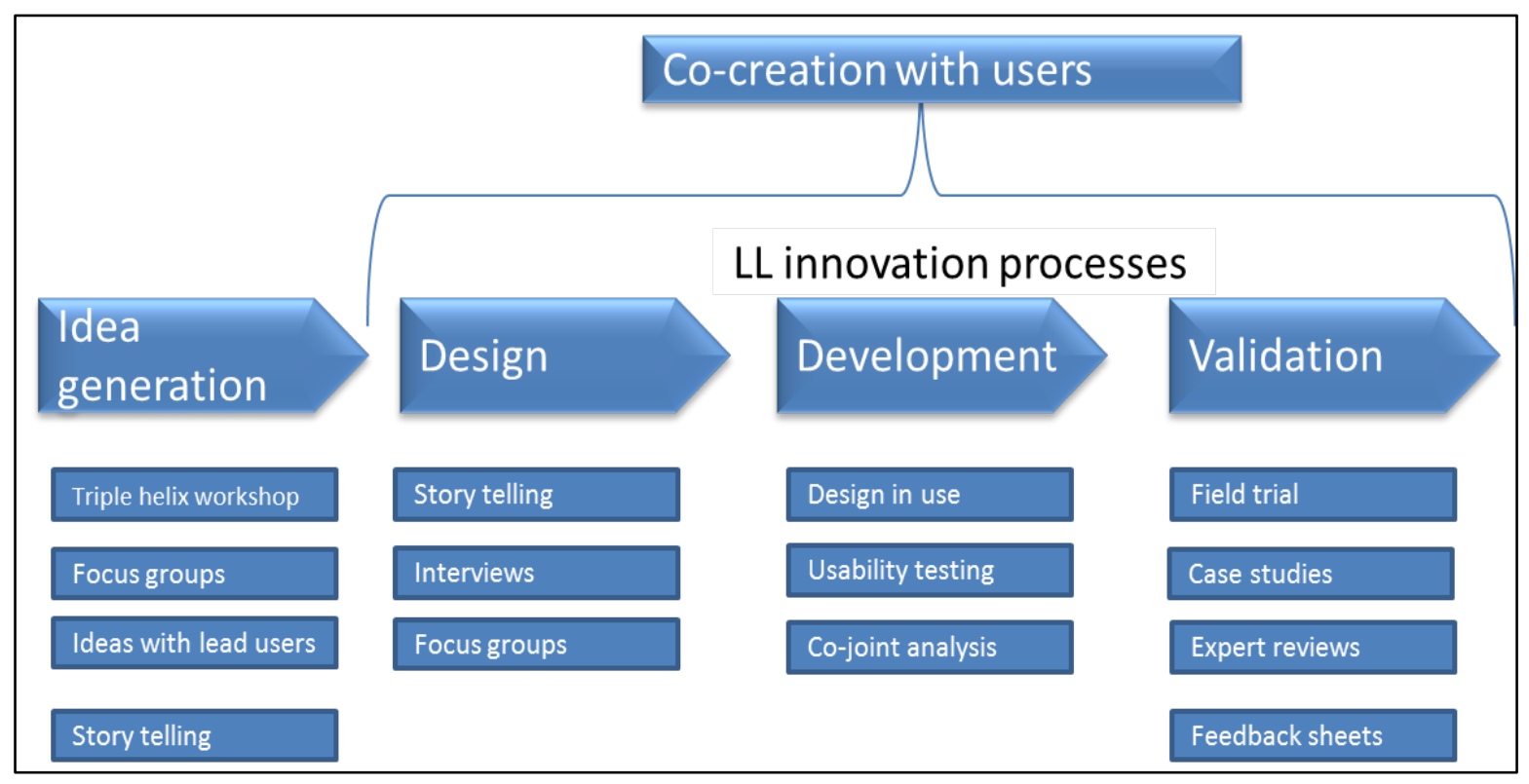

Figure 3: Role of users as co-creators during innovation processes Source: Adapted from Guzmán et al. (2013)

The inputs of users were applied to develop the Living Lab from idea through to implementation and validation. Thus, they have become co-creators of the Living Lab subfocus on ML.

\subsubsection{Key success factors}

The last discussion in this section focuses on the key success factors identified by LLISA, as applied to the sub-LL focus group for ML. The success factors were identified as a commonly owned vision, strong leadership, self-sustainability, sense of challenges, face-toface meetings, a strong host, and support for sustainability.

Commonly owned vision: The primary goal of the ML focus is linked to the investigation of challenges and opportunities in the field. All projects are inter-disciplinary, multi-participant projects. Most of the projects are not highly dependent on individuals. The nature of the research field creates opportunity for the development of new tools and methodologies. A variety of training modules were already developed to support educators as well as students in the field. Research on e-resource sourcing and evaluation is near completion and impacts on the e-resource development project as gaps are identified in existing resources. A database of participants and other stakeholders is also being developed. 
Strong leadership: The core members of the LL are at this stage too focused within the Science, Mathematics and Technology Education fields. However, the participants in the various projects represent other fields and have most of the necessary skills for the research and the evaluation of the research. A skill that is lacking is that of Application Development, which is necessary in the e-resource development project.

Self-sustainable: The LL and the ML focus is specifically self-sustainable at this stage and is driven by projects. There are quite a number of research projects available. However, it is realistic to assume that developments (and therefor also funding opportunities) in the Mobile field will eventually slow down. The living nature of a Living Lab implies that one should be open to the fact that it will also eventually die, and therefore, one should be aware in recognising those signs.

Sense of challenges: The eventual aim would be that each project manager should be aware of the challenges of participants, the community, other stakeholders, as well as challenges within activities and research. Participants do provide valuable input in this regard, but currently the main responsibility for challenge identification and reaction lies with the Research Unit manager. This is not an ideal situation, and will have to be addressed.

Face-to-face meetings: Regular face-to-face meetings are held (as needed) for separate projects, such as the ML projects. Integrated meetings between different focus areas and for the Education LL are planned for the future.

Hosted by a strong existing organisation: A university that supports research and developments in ICT in Education is hosting the LL and the ML sub-field. The Faculty of Education also provides an open environment for experimentation and innovation in Educational solutions to challenges. Being a research intensive university also implies that methodological rigour is emphasised at the institution.

Support for sustainability: Departments at the university that can provide support were mentioned previously. University funding is not readily available, but the university provides support in applications for outside funding for research and innovation. Capacity building within the LL is developing in the ML field through the development of training material, guidelines, presentation, and training. The content created is licenced under the Common Core licensing. Monitoring and evaluation is part of each project as prescribed by the project, and as part of the institutional reporting processes.

\subsection{Business model}

The nature of the Education LL, hosted at a research-intensive university, impacts on the type of business model established. LLs in South Africa are usually situated within rural communities and aim for sustainable innovations to support those communities. The Education LL, however, is situated within a research community, but services the wider, including rural, education community, as well as industry in South Africa. Being a research unit also implies that, besides the products and impact of the LL on its stakeholders, research outputs are of paramount importance.

Schaffers et al. (Schaffers, Cordoba, Hongisto, Kallai, Merz, \& Van Rensburg, 2007) propose a business model for LLs as a two-dimensional model. On the one hand, it depicts the development phases of an LL (Initialisation, Operation and Commercialisation), but on the other hand, it should support sustainable partnership creation, provide an environment for new business development, and opportunities to capitalise on network effects. These 
dimensions, as adapted for the Education LL, are illustrated in table 2. In the case of the Education LL, research output is suggested as a fourth support aspect. The phases could possibly be linked to the LL innovation processes of Ideation, Co-creation and Venturing (as illustrated in Figure 3), as well as to the AI process followed during the development of the Education LL.

The ML course for the 21st Century facilitators' project was used to complete the business model as an example.

Table 2: Education LL business model. Source: Adapted from Schaffers et al. (2007)

\begin{tabular}{|c|c|c|c|}
\hline $\begin{array}{l}\text { AI process } \\
\text { (Schaffers et } \\
\text { al., 2007) } \\
\text { LL } \\
\text { innovation } \\
\text { processes }\end{array}$ & $\begin{array}{l}\text { Phase } 1 \\
\text { Dream/Design. } \\
\text { Initialisation. } \\
\text { Ideation. }\end{array}$ & $\begin{array}{l}\text { Phase } 2 \\
\text { Development/Apply. } \\
\text { Operation. } \\
\text { Co-creation. }\end{array}$ & $\begin{array}{l}\text { Phase } 3 \\
\text { Implement. } \\
\text { Commercialisation. } \\
\text { Venturing. }\end{array}$ \\
\hline $\begin{array}{l}\text { Support } \\
\text { partnership } \\
\text { creation }\end{array}$ & $\begin{array}{l}\text { Invite stakeholders } \\
\text { to give input into } \\
\text { the course content } \\
\text { and strategies. } \\
\text { Develop a concept } \\
\text { course and share } \\
\text { with stakeholders. }\end{array}$ & $\begin{array}{l}\text { Present a Pilot course } \\
\text { to inter-disciplinary } \\
\text { groups of participants. } \\
\text { Learn from } \\
\text { participants' } \\
\text { experience to co- } \\
\text { create new examples } \\
\text { of ML applications. }\end{array}$ & $\begin{array}{l}\text { Present the course to } \\
\text { different groups through the } \\
\text { University Continuous } \\
\text { Development Unit. } \\
\text { Users can use new co- } \\
\text { created products to improve } \\
\text { the teaching of an ML } \\
\text { course or in their own } \\
\text { environments, which can } \\
\text { also lead to } \\
\text { commercialisation }\end{array}$ \\
\hline $\begin{array}{l}\text { Support new } \\
\text { business } \\
\text { development }\end{array}$ & $\begin{array}{l}\text { Establish possible } \\
\text { applications of the } \\
\text { ML course in other } \\
\text { educational } \\
\text { environments (HE, } \\
\text { Basic Education, } \\
\text { Industry). }\end{array}$ & $\begin{array}{l}\text { Adapt the generic } \\
\text { course to the needs of } \\
\text { different } \\
\text { environments. Get } \\
\text { feedback from users } \\
\text { on examples of } \\
\text { applications. }\end{array}$ & $\begin{array}{l}\text { Ask industry to test } \\
\text { examples and provide } \\
\text { feedback if possible. }\end{array}$ \\
\hline $\begin{array}{l}\text { Support } \\
\text { research } \\
\text { output }\end{array}$ & $\begin{array}{l}\text { Conceptualise a } \\
\text { research focus. }\end{array}$ & $\begin{array}{l}\text { Develop the research } \\
\text { focus with input from } \\
\text { participants. Initialise } \\
\text { individual, as well as } \\
\text { collaborative research. }\end{array}$ & $\begin{array}{l}\text { Publish articles and present } \\
\text { at conferences. }\end{array}$ \\
\hline $\begin{array}{l}\text { Support } \\
\text { network } \\
\text { establishment }\end{array}$ & $\begin{array}{l}\text { Build database of } \\
\text { stakeholders and } \\
\text { users. }\end{array}$ & $\begin{array}{l}\text { Add more to database } \\
\text { if ML course is } \\
\text { presented. }\end{array}$ & $\begin{array}{l}\text { Users start creating own } \\
\text { communities of practice to } \\
\text { apply ML course examples } \\
\text { in own environment and to } \\
\text { share lessons learnt. }\end{array}$ \\
\hline
\end{tabular}

\subsection{Challenges during establishment process}

The biggest challenge during the establishment of the LL was the institutional processes. Processes are complex and time consuming. It took a lot of time to follow the route of 
approvals, as many committees meet only a few times per annum. Ethical clearance processes are also complex and time consuming. Within the establishment process of the LL itself, it was quite a challenge to identify and meet with all the different stakeholders. This is probably due to the fact that the focus of the Lab is broad and that there are so many possible stakeholders. Finalisation of the structure and nature of the LL was challenging, as it is important that the LL reflects the users' views and incorporates their needs. It is also important for the management team to understand the living nature of the Lab, which implies a fluidity in the structure of the Lab.

The nature of the Living Lab paradigm implies that networking is one of the key aspects of a successful Living Lab. Even though this process has started and the network is growing, the management of this network, as well as the maintenance of a database of stakeholders and interventions remains a challenge. Currently, the Living Lab is self-sustainable, as the projects provide the little funding needed for the management of the Lab. Growth might imply that an administrator and/or a full time manager will have to be appointed. The guidelines from the literature on Living Labs, as well as the support and guidelines from LLiSA, did provide some structure in the messy, challenging and exciting establishment process of the Education LL.

\section{Conclusion}

The question that guided this discussion in this article was: How can the development of an Education LL at a research intensive university comply with the conditions for successful establishment of LLs in South Africa? These discussions illustrated the establishment process of a Living Lab for Innovative Research in Education in South Africa at the hand of Living Labs' core values, stakeholders and key success factors. The establishment of this Lab was a challenging and time consuming process, but it was successful, as illustrated in the discussion on the Mobile Learning sub-focus within this Lab. The challenges identified are not insurmountable. The notion throughout was that this process had a life of its own - which may be an indication that this is indeed a Living Laboratory.

The advantages of inter-disciplinary and collaborative research in a globalised society are supported in the comments from one of the participants within the Mobile Learning focus.

The social process of meeting like-minded people to engage with and in the research of evaluating educational apps across the curriculum is undeniably meritorious. Every couple of weeks, the e-learning group comes together to discuss, deliberate and plan the way forward in the process of sourcing, evaluating and eventually implementing educational apps. Academics from different fields and interests, as well as different ages and stages share a common goal of being passionate about the use of technology in teaching and learning. With this as a common goal, the collaboration and knowledge sharing between members has highlighted the worthiness of this synergistic relationship.

It seems as if the vision of the Education Living Lab can be realised: to be a catalyst of innovation, to create a collaborative environment, and to build capacity. 


\section{References}

Babbie, E. \& Mouton, J. (2001). The practice of social research. Cape Town: Oxford University Press.

Badat, S. \& Jayed, Y. (2014). Post-1994 South African Education: The challenge of social justice. The ANNALS of the American Academy of Political and Social Science, 652(1), 127-148.

Bidin, S. \& Ziden, A.A. (2013). Adoption and application of Mobile Learning in the education industry. 6th International Conference on University Learning and Teaching. Elsevier, 720-729.

Bushe, G.R. (2013). The appreciative inquiry model. In Kessler, E. (ed.), The Encyclopaedia of Management Theory. London: Sage Publications.

Chesbrough, H. (2003). Open innovation: the new imperative for creating and profiting from technology. Harvard: Harvard Business School Press.

Coetzee, H., Du Toit, I. \& Herselman, M. (2012). Living Labs in South Africa: an analysis based on five case studies. The Electronic Journal for Virtual Organization E Networks. Vol 14, 29-31.

Cunningham, P., Cunningham, M. \& Herselman, M.E. (2012). Socio-economic impact of growing Living Labs and Living Lab networks into Africa. IST-Africa 2012 Conference Proceedings, Dar es Salaam, Tanzania, 09-11 May 2012.

Cunningham, P., Herselman, M. \& Cunningham, M. (2012). Supporting the evolution of sustainable Living Labs and Living Labs networks in Africa. Retrieved from http://www.istafrica.org/home/files/Supporting the_Evolution_of_Sustainable_Living Labs and Living Labs Networks in Africa.pdf [Accessed: 31 January 2015].

De Arias, A.R., Masi, S.D., Dorigo, D., Rojas, F.A., Vega, M. C. \& Rolon, M. (2014). Living Labs, spaces for open innovation and technology transfer. An alternative to the solution of social problems in Paraguay. Social Sciences, 3(3), 74-79.

Department of Science and Technology. 2007. ICT RED Innovation Strategy. Retrieved from

http://www.ist-

africa.org/home/files/RSA ICTResearchDevelopmentInnovationStrategy Final.pdf. [Accessed: 12 March 2015].

ENoLL (2014). Open Living Labs by ENOLL. Retrieved from http://www.openlivinglabs.eu/. [Accessed: 31 January 2015].

Fahy, C., Ponce De Leon, M., Ståhlbröst, A., Schaffers, H. \& Hongisto, P. (2007). Services of living labs and their networks. In: P. Cunningham \& M. Cunningham (Eds.), Expanding the Knowledge Economy: Issues, Applications, Case Studies. IOS Press, Amsterdam, 713-721.

Følstad, A. (2008). Living labs for innovation and development of information and communication technology: A literature review. The Electronic Journal for Virtual Organizations and Networks, 10 (Special Issue on Living Labs), August 2008. Vol 10, 99-131. 
Geerts, G. (2011). A design science research methodology and its application to accounting information systems research. International Journal of Accounting Information Systems, $12(2), 142-151$.

Guzmán, G.J., De la Cruz, N.M., Schaffers, H. \& Kulkki, S. (2007). Methodological framework for human and user centric rural living labs. In: P. Cunningham \& $\mathrm{M}$. Cunningham (Eds.), Expanding the Knowledge Economy: Issues, Applications, Case Studies. IOS Press, Amsterdam, 730-737.

Guzmán, J.G., Del Carpio, F.A., Colomo-Palacios, R. \& De Diego, V. M. (2013). Living labs for user-driven innovation: a process reference model. Research-Technology Management, 56(3), 29-39.

Guzmán, J.G., Schaffers, H., Del Carpio, Á.F. \& De la Cruz, M.N. (2010). Assessment of results and impacts of the C@R rural Living Labs. Living Labs for Rural Development, Madrid: TRAGSO and FAO.

Merz, C., Friedland, C., de Louw, R., Dörflinger, O., Maritz, J., van Rensburg, J. \& Naudé, A. (2010). Sekhukhune: a Living Lab stimulating economic growth of rural microenterprises in South Africa (Chapter 8), In: H. Schaffers, J.C. Guzmán, M.N de la Cruz \& C. Merz, (Eds.). Living Labs for Rural Development Results from the C@R Integrated Project. Retrieved from: http://www.amicommunities.eu/pub/bscw.cgi/d700042/C\%40Rbookfinal.pdf. [Assessed: 02 March 2015].

Herselman, M. (2011). Living Labs in Southern Africa network. PowerPoint presentation at $3^{\text {rd }}$ Annual LLiSA Workshop in Grahamstown, Eastern Cape.

Innovation-Management. (2015). Managing change and innovation: Getting the most from the Innovation funnel. Retrieved from: http://www.innovationmanagement.org/managing-change-and-innovation.html [Accessed: 02 March 2015].

Katzy, B. (2012). Designing valuable business models for Living Labs. Technology innovation management review, September 2012. Retrieved from: http://timreview.ca/article/604. [Accessed: 02 March 2015].

Lievens B., Van den Broeck, W. \& Pierson, J. (2006). The mobile digital newspaper: embedding the news consumer in technology development by means of living lab research. Presented at Congress of International Association for Media and Communication Research, IAMCR, Cairo, Egypt.

LLiSA. (2014). Living Labs in Southern Africa. Retrieved from: http://lisa.meraka.org/. [Accessed: 31 January 2015].

MacEachren, A.M., Cai, G., McNeese, M., Sharma, R. \& Fuhrmann, S. (2006). Crisis management: geo-collaborative crisis management: Designing technologies to meet realworld needs. International Conference on Digital Government Research, San Diego, California, pp. 71-72, ACM Press.

Mulder, I., Fahy, C., Hribernik, K., Velthausz, D., Feurstein, K., Garcia, M., Schaffers, H., Mirijamdotter, A. \& Ståhlbröst, A. (2007). Towards harmonized methods and tools for living labs. In: P. Cunningham \& M. Cunningham (Eds.), Expanding the Knowledge Economy: Issues, Applications, Case Studies. IOS Press, Amsterdam, 722729. 
Santoro, R. \& Conte, M. (2009). Living Labs in open innovation functional regions. Proceedings of the 15th International Conference on Concurrent Enterprising 2009, Leiden.

Schaffers, H. \& Turkama, P. (2012). Living Labs for cross-border systemic innovation. Technology Innovation Management Review, (September 2012: Living Labs). Vol 1, 25-31.

Schaffers, H., Cordoba, M.G., Hongisto, P., Kallai, T., Merz, C. \& Van Rensburg, J. (2007). Exploring business models for open innovation in rural Living Labs. 13th International Conference on Concurrent Enterprising, Sophia-Antipolis, France.

Smit, D., Herselman, M., Eloff, J.H.P., Ngassam, E., Venter, E., Ntawanga, F., Chuang, J. \& Van Greunen, D. (2011). Formalising living labs to achieve organisational objectives in emerging economies. Presented at IST-Africa 2011 Conference E Exbibition, Gaborone, Botswana.

Statistics South Africa. (2010). General household survey 2010. Pretoria: StatsSA. Retrieved from: http://www.statssa.gov.za/publications/P0318/P0318June2010.pdf, [Accessed: 19 March 2012].

Statistics South Africa. (2012). Latest key indicators. Retrieved from: http://www.statssa.gov.za/keyindicators/keyindicators.asp [Accessed 12 March 2015].

United Nations Development Programme. (2011). Human development report 2011. Sustainability and equity: a better future for all. New York: United Nations. Retrieved from:

http://www.za.undp.org/content/dam/south_africa/docs/Reports/Project\%20Docume nts/HDR_2011_EN_Complete.pdf [Accessed: 11 March 2015].

Yin, R.K. (2013). Case study research: Design and methods. London: Sage publications. 